\title{
Eukaryotic Translation Initiation Factor 4 Gamma Family
}

National Cancer Institute

\section{Source}

National Cancer Institute. Eukaryotic Translation Initiation Factor 4 Gamma Family. NCI

Thesaurus. Code C129656.

A family of proteins that are part of the eukaryotic translation initiation factor $4 \mathrm{~F}$ complex

(elF4F). The members of the family play a role in recognition of the $5^{\prime}$ cap on messenger RNA and the initiation of translation. 